\title{
Pengaruh Rasio Keuangan dan Pertumbuhan Perusahaan terhadap Dividend Payout Ratio (DPR) dan Implikasinya pada Harga Saham Perusahaan Perbankan yang Listing di Bursa Efek Indonesia (BEI)
}

\author{
Megamawarni \\ Aliah Pratiwi \\ Manajemen, Sekolah Tinggi Ilmu Ekonomi Bima, Indonesia \\ Korespondensi penulis: aliahpratiwi@ymail.com
}

\begin{abstract}
The rapid technological developments have an impact on the opening of global trade opportunities so that banks that carry out intermediary functions in the financial sector will be increasingly needed. The purpose of this study was to analyze the effect of financial ratio and company growth on the stock price of banks with the status of StateOwned Enterprises (SOE) listed on the Indonesia Stock Exchange (IDX) with Dividend Payout Ratio (DPR) as an intervening variable. This study is quantitative research with an associative approach. The research population includes 44 banking companies listed on the Indonesia Stock Exchange (IDX). The sample in this study amounted to four banks. The sampling technique used is purposive sampling. This study uses secondary data with data analysis methods used multiple linear regression analysis, partial test (t-test), and path analysis with the help of the SPSS version 23 application. This study indicates that DER significantly affects DPR, while ROE and company growth do not affect DPR. Furthermore, the DPR has a significant effect on stock prices, while DER and ROE have a significant effect on stock prices through the Dividend Payout Ratio (DPR), and company growth does not affect stock prices mediated by the Dividend Payout Ratio (DPR).
\end{abstract}

Keywords: Company growth; Debt to Equity Ratio (DER); Dividend Payout Ratio (DPR); Return on Equity (ROE); Stock price.

\begin{abstract}
Abstrak. Perkembangan teknologi yang pesat berdampak pada terbukanya peluang perdagangan global, sehingga bank yang menjalankan fungsi perantara dalam bidang keuangan akan semakin dibutuhkan. Tujuan penelitian ini adalah untuk menganalisis pengaruh rasio keuangan dan pertumbuhan perusahaan terhadap harga saham perbankan berstatus Badan Usaha Milik Negara (BUMN) yang listing di Bursa Efek Indonesia (BEI) dengan Dividend Payout Ratio (DPR) sebagai variabel intervening. Penelitian ini merupakan penelitian kuantitatif dengan pendekatan asosiatif. Populasi penelitian mencakup 44 perusahaan per-
\end{abstract}


bankan yang terdaftar di Bursa Efek Indonesia (BEI). Sampel dalam penelitian ini berjumlah empat bank. Teknik penentuan sampel yang digunakan adalah purposive sampling. Penelitian ini menggunakan data sekunder dengan metode analisis data yang digunakan adalah analisis regresi linear berganda, uji parsial ( $t$-test), dan analisis jalur dengan bantuan aplikasi SPSS versi 23. Hasil penelitian ini menunjukkan bahwa DER (debt to equity ratio) berpengaruh secara signifikan terhadap DPR (dividend payout ratio), sedangkan ROE (return on equity) dan pertumbuhan perusahaan tidak berpengaruh terhadap DPR. Selanjutnya, DPR berpengaruh secara signifikan terhadap harga saham, sedangkan DER dan ROE berpengaruh signifikan terhadap harga saham melalui Dividend Payout Ratio (DPR), serta pertumbuhan perusahaan tidak berpengaruh terhadap harga saham yang dimediasi oleh Dividend Payout Ratio (DPR).

Kata kunci: Debt to Equity Ratio (DER); Dividend Payout Ratio (DPR); Harga saham; Pertumbuhan perusahaan; Return on Equity (ROE).

\section{Article Info:}

Received: April 25, 2021

\section{LATAR BELAKANG}

Era globalisasi yang ditandai dengan banyaknya peluang bisnis, baik di tingkat nasional maupun internasional memberikan dampak nyata pada dunia bisnis di Indonesia, yaitu perusahaan-perusahaan berkompetisi semakin ketat untuk meningkatkan kinerjanya agar lebih unggul dibandingkan perusahaan lainnya. Gambar 1 menunjukkan bahwa pada tahun 2016, pertumbuhan ekonomi Indonesia mencapai 5,03\%. Pada tahun 2017, pertumbuhan ekonomi tersebut mengalami kenaikan $0,04 \%$ dari tahun sebelumnya menjadi 5,07\% . Peningkatan pertumbuhan tersebut dikarenakan peningkatan di sektor industri pengolahan, sektor kontruksi, sektor perdagangan dan sektor pertanian.

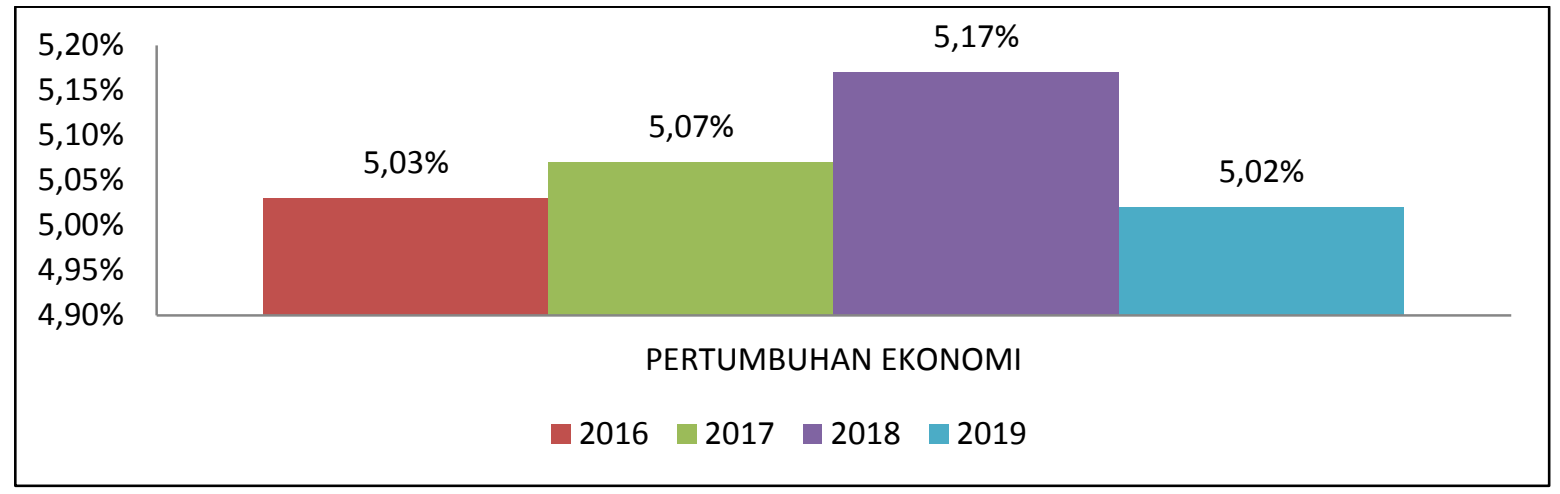

Sumber: BPS (2020).

Gambar 1. Pertumbuhan Ekonomi Indonesia Periode 2016-2019 
Tahun 2018, pertumbuhan Indonesia kembali mengalami kenaikan 0,10\% dibandingkan tahun sebelumnya menjadi $5,17 \%$ sebagai akibat produksi semen yang meningkat pada kuartal IV tahun 2018, penjualan mobil secara wholesale, serta nilai ekspor dan impor. Namun, pada tahun 2019 pertumbuhan ekonomi Indonesia mengalami penurunan sebesar 0,15\% dibandingkan tahun 2018 menjadi 5,02\% karena ada tekanan internasional akibat belum usainya perang dagang antara Amerika Serikat dan China, politik di kawasan Timur Tengah yang mengalami ketegangan, fluktuatifnya harga komoditas, keterlambatan kegiatan industri di banyak negara, dan belanja pemerintah Indonesia mengalami kenaikan pada kuartal IV tahun 2019. Dari kondisi tersebut, pertumbuhan ekonomi Indonesia relatif cukup stabil, meskipun mengalami penurunan pada tahun 2019. Pertumbuhan ekonomi dan perbankan suatu negara akan terdampak oleh bannyaknya peluang dalam perdagangan global, karena bank menjalankan fungsi perantara dalam bidang keuangan sehingga kinerja bank akan sangat dibutuhkan. Investor akan tertarik berinvestasi jangka panjang di perusahaan perbankan, karena bank memiliki nilai kapitalisasi pasar yang besar, sehingga potensi pertumbuhan perusahaannya meningkat.

Jumlah kapitalisasi pasar terbesar adalah PT Bank Rakyat Indonesia (Persero), Tbk. dengan nilai kapitalisasi Rp537,3 triliun (Gambar 2). Posisi kedua ditempati oleh PT Bank Mandiri (Persero), Tbk. jumlah kapitalisasi pasar sebesar Rp354,6 triliun. PT Bank Negara Indonesia (Persero), Tbk. menempati urutan ketiga dengan nilai kapitalisasi pasar sebesar Rp144,9 triliun, sedangkan di posisi keempat ditempati oleh PT Bank Tabungan Negara (Persero), Tbk. dengan jumlah kapitalisasi pasar sebesar Rp22,2 triliun. Potensi meningkatnya pertumbuhan nilai suatu perusahaan dapat dipengaruhi oleh semakin tingginya nilai kapitalisasi pasarnya, sehingga kondisi tersebut diharapkan dapat memberikan tingkat return yang tinggi dan menjadi daya tarik bagi investor. Turunnya harga saham dan jumlah saham yang beredar akan menyebabkan kapitalisasi pasar perusahaan juga menurun, atau sebaliknya (Kumaidi \& Asandimitra, 2017). Penelitian yang dilakukan (Pambayun \& Sulasmiyati, 2017) menyatakan bahwa asset growth berpengaruh signifikan terhadap Dividend Payout Ratio (DPR). Artinya, jika tingkat asset growth yang dihasilkan perusahaan mengalami peningkatan, maka hal itu akan menyebabkan menurunnya Dividend Payout Ratio (DPR).

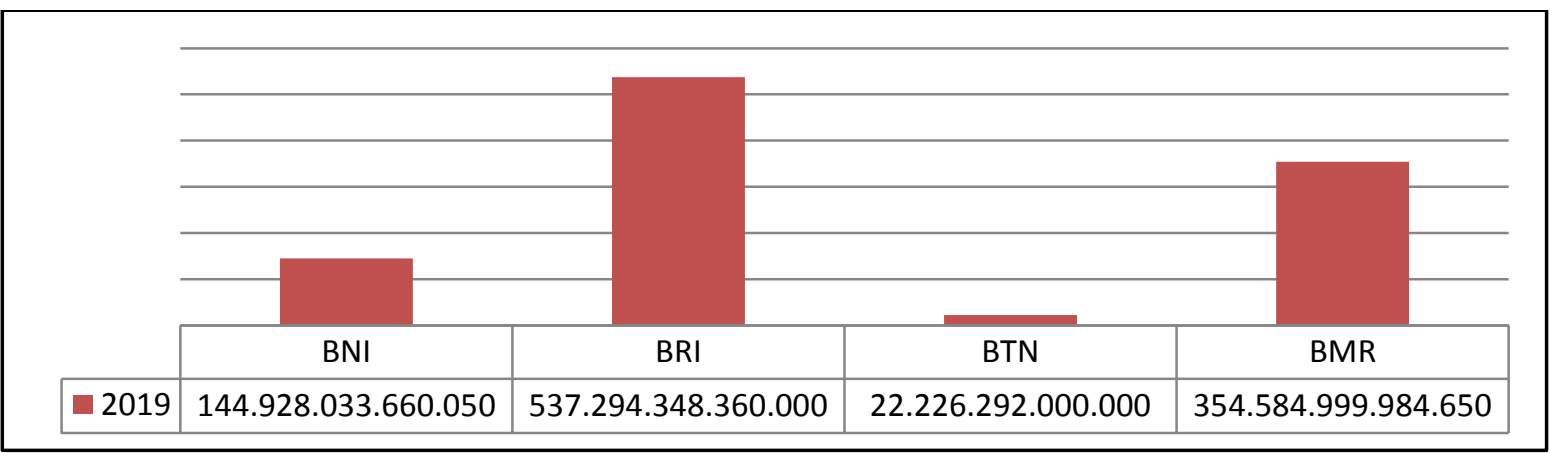

Sumber: Tim Edusaham (2020).

Gambar 2. Kapitalisasi Pasar Perusahaan Perbankan BUMN per Desember 2019 
Dalam pengambilan keputusan berinvestasi, investor akan sangat membutuhkan laporan keuangan perusahaan. Salah satu cara agar investor mengetahui kondisi perusahaan adalah analisis laporan keuangan perusahaan berdasarkan data laporan keuangan yang mengukur kinerja keuangannya. Jika tingkat dividen meningkat dari tahun ke tahun, maka peningkatan tersebut akan menarik minat investor untuk berinvestasi dan berdampak pada naiknya harga saham perusahaan karena banyaknya permintaan saham perusahaan tersebut. Jika permintaan saham di pasar modal mengalami kenaikan, maka harga saham perusahaan pun akan mengalami kenaikan. Salah satu faktor penyebab naik turunnya harga saham dan daya tarik investor berinvestasi adalah kebijakan dividen. Kebijakan dividen berhubungan dengan besarnya nilai Dividend Payout Ratio, yaitu rasio yang mengukur kemampuan perusahaan menggunakan sumber-sumber yang dimiliki seperti modal, pendapatan, atau pun aktiva dalam memperoleh laba (Aryanti \& Jayanti, 2020b). Keputusan dividen adalah bagian dari keputusan penggunaan dana perusahaan dalam kebijakan pembelanjaan internal perusahaan. Karena besar atau kecilnya dividen yang dibagikan dapat mempengaruhi nilai laba ditahan. Laba ditahan merupakan salah satu sumber dana internal perusahaan.

Debt to Equity Ratio (DER) merupakan rasio untuk melihat nilai utang terhadap modal. Rasio ini mengukur seberapa jauh aktifitas perusahaan dibiayai oleh utang, artinya semakin tinggi nilai rasio menunjukkan keadaan yang kurang baik bagi perusahaan karena akan semakin besar resiko yang ditanggung perusahaan jika mengalami kegagalan (Aryanti \& Jayanti, 2020b). Pada dasarnya, peningkatan utang mempengaruhi besar kecilnya laba bersih. Bagi para pemegang saham, laba bersih termasuk dividen yang diterima merupakan kewajiban untuk membayar utang yang lebih diutamakan daripada pembagian dividen. Penelitian yang dilakukan Wahyuni dan Hafiz (2018) menyatakan bahwa Debt to Equity Ratio (DER) berpengaruh signifikan secara parsial terhadap Dividend Payout Ratio (DPR), yaitu semakin besar nilai DER perusahaan, maka semakin besar pula dividen yang dibagikan oleh perusahaan.

Saat ini, para investor banyak menggunakan rasio Return on Equity (ROE) untuk mengukur tingkat keuntungan dan mengetahui tingkat keefektifan dan efisiensi pengelolaan modal sendiri (Aryanti \& Jayanti, 2020b), karena kemampuan perusahaan untuk memperoleh laba yang tersedia bagi pemegang saham perusahaan dapat terlihat dengan jelas dari besar-kecilnya utang perusahaan, sehingga semakin tinggi utang perusahaan, maka nilai rasio ROE juga semakin tinggi. Alat ukur kinerja perusahaan yang paling populer antara penanam modal dan manajer senior sebagai hasil atas hak pemegang saham adalah Return on Equity atau ROE (Rohmawati \& Herawati, 2013). ROE digunakan untuk mengukur keefektifan perusahaan dalam menghasilkan keuntungan dengan memanfaatkan ekuitas yang dimilikinya. Penelitian Aryanti dan Jayanti (2020a) menyebutkan bahwa ROE berpengaruh signifikan terhadap harga saham melalui DPR. Artinya, DPR dapat mempengaruhi ROE untuk meningkatkan harga saham perusahaan. Dari uraian tersebut, tujuan penelitian ini adalah menganalisis pengaruh rasio keuangan dan pertumbuhan perusahaan terhadap harga saham perbankan berstatus Badan Usaha Milik Negara (BUMN) yang listing di Bursa Efek Indonesia (BEI) dengan Dividend Payout Ratio (DPR) sebagai variabel intervening. 


\section{KAJIAN TEORITIS}

\section{Rasio Keuangan}

\section{a. Solvabilitas}

Salah satu jenis rasio keuangan yang digunakan untuk melihat kemampuan perusahaan menggunakan utang untuk membiayai investasi adalah rasio solvabilitas (Utari, Purwanti, \& Prawironegoro, 2014). Penelitian ini menggunakan Debt to Equity Ratio (DER) sebagai indikator untuk mengukur rasio solvabilitas. Semakin tinggi nilai DER perusahaan, maka jumlah utang yang dimiliki perusahaan semakin besar dibandingkan dengan jumlah modal sendiri, sehingga beban perusahaan terhadap pihak luar (kreditur) pun akan semakin besar (Nurcahayani \& Daljono, 2014). Rasio Debt to Equity Ratio (DER) diformulasikan pada persamaan [1] sebagai berikut (Utari et al., 2014):

$$
\mathrm{DER}=\frac{\text { TOTAL UTANG }}{\text { TOTAL EKUITAS }} \times 100 \%
$$

\section{b. Profitabilitas}

Salah satu rasio keuangan yang digunakan untuk melihat kemampuan manajemen untuk memperoleh laba adalah rasio profitabilitas (Utari et al., 2014). Penelitian ini menggunakan Return on Equity (ROE) sebagai indikator untuk mengukur rasio profitabilitas. Bagi para investor, ROE adalah rasio penting karena dapat menunjukkan kemampuan perusahaan mendapatkan laba setelah pajak dengan menggunakan modal sendiri perusahaan dan dapat mengukur tingkat keuntungan atas investasi yang telah dilakukan (Aryanti \& Jayanti, 2020b). Rasio Return on Equity (ROE) diformulasikan dalam persamaan [2] sebagai berikut (Utari et al., 2014):

$$
\text { ROE }=\frac{\text { LABA BERSIH }}{\text { TOTAL EKUITAS }} \times 100 \%
$$

\section{Pertumbuhan Perusahaan}

Pertumbuhan perusahaan adalah perubahan (naik/turun) aset total dari tahun ke tahun yang diharapkan tumbuh secara terus menerus dan konstan. Pertumbuhaan perusahaan yang baik akan terjadi ketika kondisi ekonomi suatu negara dalam kondisi yang baik pula dan pada umumnya pertumbuhan perusahaan yang baik juga dipengaruhi oleh manajemen profesional (Utari et al., 2014). Berdasarkan sudut pandang para investor, perusahaan yang memiliki aspek menguntungkan dapat dilihat dari pertumbuhan asetnya (Paramitasari, 2014). Penelitian ini menggunakan asset growth sebagai indikator untuk mengukur partumbuhan perusahaan. Asset growth diformulasikan dalam persamaan [3] sebagai berikut (Utari et al., 2014):

$$
\text { Asset Growth }=\frac{\text { Total Asset Tahun } \mathrm{t}}{\text { Total Asset Tahun } \mathrm{t}-1} \mathrm{X} 100 \%
$$




\section{Kebijakan Dividen}

Keuntungan yang harus dibayarkan kepada para investor dan nilai yang harus diinvestasikan kembali dapat ditentukan melalui kebijakan dividen (Utari et al., 2014). Penelitian ini menggunakan Dividend Payout Ratio (DPR) sebagai indikator untuk mengukur kebijakan dividen. Dividend Payout Ratio (DPR) adalah persentase tertentu dari laba perusahaan yang dibayarkan sebagai deviden tunai kepada pemegang saham (Darmadji \& Fakhruddin, 2012). Semakin tinggi persentase Dividend Payout Ratio (DPR), maka para investor akan semakin diuntungkan, tetapi internal financial perusahaan akan semakin lemah karena memperkecil laba ditahan (Diantini \& Badjra, 2016). Dividend Payout Ratio (DPR) diformulasikan pada persamaan [4] sebagai berikut (Gitosudarmo \& Basri, 2019):

$$
\text { DPR }=\frac{\text { DIVIDEN }}{\text { LABA BERSIH }} \times 100 \%
$$

\section{Harga Saham}

Harga saham adalah harga per lembar saham perusahaan yang ditentukan oleh besarnya permintaan dan penawaran atas saham tersebut yang terjadi di pasar modal (Hartono, 2017). Dalam penelitian ini, yang digunakan sebagai indikator harga saham adalah harga saham pada penutupan akhir.

\section{Pengaruh Debt to Equity Ratio (DER) terhadap Dividend Payout Ratio (DPR)}

DER merupakan rasio yang digunakan untuk melihat kemampuan perusahaan dalam memenuhi kewajibannya (Wahyuni \& Hafiz, 2018). Semakin rendah persentase DER, maka kemampuan perusahaan membayar kewajibannya semakin tinggi. Jika beban utang tinggi, maka kemampuan perusahaan membagikan dividennya menjadi semakin rendah (Hanif \& Bustamam, 2017). Penelitian yang pernah dilakukan oleh Perpatih (2016), Ulfa dan Yuniati (2016), serta Wahyuni dan Hafiz (2018) menyatakan bahwa DER berpengaruh signifikan secara parsial terhadap DPR, yaitu semakin besar nilai DER perusahaan, maka semakin besar pula dividen yang dibagikan oleh perusahaan. Pada penelitian yang lain, Astiti, Yuniarta, dan Sujana (2017) serta Hanif dan Bustamam (2017) menemukan bahwa DER tidak berpengaruh terhadap DPR. Dari uraian yang kontradiktif tersebut, maka penelitian ini mengajukan hipotesis kesatu (H1) sebagai berikut:

\section{H1: DER berpengaruh signifikan terhadap DPR.}

\section{Pengaruh Return on Equity (ROE) terhadap Dividend Payout Ratio (DPR)}

ROE merupakan perbandingan antara laba bersih setelah pajak dengan ekuitas perusahaan, semakin tinggi ROE menandakan bahwa keuntungan yang diperoleh investor semakin besar, karena pengelolaan ekuitas yang dimiliki oleh perusahaan tersebut cukup baik. Selanjutnya, semakin tinggi keuntungan yang diperoleh perusahaan, maka investor cenderung lebih menyukai saham perusahaan tersebut (Nugraha \& Sudaryanto, 2016). Semakin besar kemampuan perusahaan menghasilkan keuntungan, maka Dividend Payout Ratio 
(DPR) yang dibagikan juga semakin besar, sehingga minat investor terhadap saham perusahaan akan semakin tinggi pula (Anjasari, Florencia, Hidayat N., 2020). Penelitian oleh Nerviana (2015), Sulaeman (2018), serta Purba, Sheren, Valent, dan Angeline (2019) menyatakan bahwa ROE berpengaruh signifikan terhadap DPR, yaitu semakin besar nilai ROE perusahaan, maka semakin besar pula Dividend Payout Ratio (DPR) yang dapat dibagikan oleh perusahaan, sedangkan penelitian oleh Perpatih (2016) serta Pamungkas, Rusherlistyani, dan Janah (2017) menyatakan bahwa ROE tidak berpengaruh terhadap Dividend Payout Ratio (DPR). Dari kontradiksi temuan tersebut, maka penelitian ini mengajukan hipotesis kedua (H2) sebagai berikut:

\section{H2: ROE berpengaruh signifikan terhadap DPR.}

\section{Pengaruh Pertumbuhan Perusahaan terhadap Dividend Payout Ratio (DPR)}

Faktor internal yang mempengaruhi DPR adalah asset growth (Pratama, Sujana, \& Werastuti, 2015). Pertumbuhan perusahaan, yang di dalam penelitian ini diukur dengan asset growth, dapat dilihat dari hasil penjualan, nilai aset, maupun laba perusahaan. Pertumbuhan perusahaan dapat ditingkatkan dengan memanfaatkan investasi. Keterkaitan antara asset growth dan DPR menunjukkan bahwa investor umumnya menginginkan untuk mendapatkan dividen yang besar, karena kepercayaan investor terhadap perusahaan akan meningkat. Penelitian oleh Sari dan Sudjarni (2015), Silaban dan Purnawati (2016), serta Pambayun dan Sulasmiyati (2017) menemukan bahwa asset growth berpengaruh signifikan terhadap DPR. Artinya, jika tingkat asset growth perusahaan mengalami peningkatan, maka kondisi tersebut dapat menyebabkan menurunnya DPR. Namun, penelitian lain yang dilakukan oleh Safrida (2014) dan Maria (2019) menyatakan bahwa asset growth tidak berpengaruh terhadap DPR. Dari kontradiksi hasil penelitian terdahulu tersebut, maka penelitian ini mengajukan hipotesis ketiga (H3) sebagai berikut:

\section{H3: Company Growth berpengaruh signifikan terhadap DPR.}

\section{Pengaruh Dividend Payout Ratio (DPR) terhadap Harga Saham}

DPR merupakan perbandingan antara dividend per share dan earning per share (Nugraha \& Sudaryanto, 2016). Semakin tinggi nilai DPR, maka kondisi tersebut akan lebih menguntungkan pihak investor, tetapi hal itu juga akan memperlemah keuangan perusahaan (Samrotun, 2015). Tingginya nilai DPR akan menarik minat investor pada saham suatu perusahaan, sehingga kondisi itu dapat meningkatkan harga sahamnya, karena banyaknya permintaan saham perusahaan tersebut. Penelitian yang dilakukan oleh Clarensia, Rahayu, dan Azizah (2012), Oktaviani dan Agustin (2017), serta Estiasih, Prihatiningsih, dan Fatmawati (2020) membuktikan bahwa DPR berpengaruh signifikan terhadap harga saham. Jika nilai DPR tinggi, maka hal itu dianggap produktif bagi investor atau sebaliknya memberikan dampak terhadap peminjaman modal. Di sisi lain, penelitian oleh Febriyani (2017) dan Girsang, Tambun, Putri, Rarasati, Nainggolan, dan Desi (2019) mennyatakan bahwa DPR tidak berpengaruh terhadap harga saham. Dari hasil penelitian yang kontradiktif tersebut, maka penelitian ini mengajukan hipotesis keempat (H4) sebagai berikut: 


\section{H4: DPR berpengaruh signifikan terhadap harga saham.}

\section{Pengaruh Debt to Equity Ratio (DER) terhadap Harga Saham melalui Dividend Payout Ratio (DPR)}

Penelitian yang dilakukan oleh Devi dan Sutrisno T. (2015), Ariyani, Andini, \& Santoso (2018), serta Lestari dan Susetyo (2020) menyebutkan bahwa DER berpengaruh signifikan terhadap harga saham melalui DPR. Temuan tersebut menunjukkan bahwa jika DER meningkat, maka DPR juga akan meningkat, sehingga kondisi itu berdampak pula terhadap naiknya harga saham perusahaan. Dari uraian tersebut, penelitian ini mengajukan hipotesis kelima (H5) sebagai berikut:

\section{H5: DER berpengaruh signifikan terhadap Harga Saham melalui DPR.}

\section{Pengaruh Return on Equity (ROE) terhadap Harga Saham melalui Dividend Payout Ratio (DPR)}

Penelitian sebelumnya oleh Pramana dan Pangestuti (2016) serta (Satar \& Jayanti, 2020) menemukan bahwa ROE berpengaruh signifikan terhadap harga saham melalui DPR. Temuan tersebut menunjukkan bahwa DPR memediasi pengaruh ROE terhadap harga saham perusahaan. Dari uraian tersebut, penelitian ini mengajukan hipotesis keenam (H6) sebagai berikut:

\section{H6: ROE berpengaruh signifikan terhadap Harga Saham melalui DPR.}

\section{Pengaruh Pertumbuhan Perusahaan (Company Growth) terhadap Harga Saham (Stock Price) melalui Dividend Payout Ratio (DPR)}

Penelitian sebelumnya oleh Deitiana (2012) menyatakan bahwa pertumbuhan perusahaan yang diukur dengan asset growth tidak berpengaruh signifikan terhadap harga saham melalui DPR. Artinya, DPR tidak menentukan pengaruh pertumbuhan perusahaan terhadap harga saham perusahaan. Dari uraian tersebut, penelitian ini mengajukan hipotesis ketujuh (H7) sebagai berikut:

\section{H7: Company Growth berpengaruh signifikan terhadap Harga Saham melalui DPR}

\section{METODE PENELITIAN}

Penelitian ini menggunakan metode penelitian kuantitatif. Metode penelitian kuantitatif dapat diartikan sebagai metode penelitian yang berlandaskan pada filsafat positivisme, digunakan untuk meneliti pada populasi atau sampel tertentu, pengumpulan data menggunakan instrumen penelitian, analisis data bersifat kuantitatif/statistik, dengan tujuan untuk menggambarkan dan menguji hipotesis yang telah ditetapkan (Sugiyono, 2019). Jenis penelitian yang digunakan dalam penelitian ini adalah jenis penelitian asosiatif. Penelitian asosiatif adalah suatu penelitian dengan tujuan untuk mengetahui hubungan antara dua variabel 
atau lebih (Sugiyono, 2019). Teknik penentuan sampel yang digunakan dalam penelitian ini adalah non-probability sampling, yaitu teknik pengambilan sampel yang tidak memberi peluang/kesempatan sama bagi setiap unsur atau anggota populasi untuk dipilih menjadi sampel (Sugiyono, 2019). Metode penentuan sampel yang digunakan pada penelitian ini adalah purposive sampling, yaitu teknik penentuan sampel dengan pertimbangan tertentu (Sugiyono, 2019).

\section{Tabel 1. Proses Penentuan Jumlah Sampel}

\begin{tabular}{|c|c|c|}
\hline No & Keterangan & Jumlah \\
\hline 1 & Jumlah perbankan yang terdaftar di BEI & 45 \\
\hline 2 & Jumlah perbankan yang bukan BUMN & 41 \\
\hline 3 & Jumlah perbankan berstatus BUMN & 4 \\
\hline
\end{tabular}
Sumber: IDX (2021).

Kriteria penentuan sampel dalam penelitian ini adalah: (1) Perusahaan perbankan yang listing di BEI; (2) Perusahaan perbankan tersebut berstatus BUMN; dan (3) Perusahaan perbankan tersebut menerbitkan laporan keuangan berturut-turut pada periode tahun 2016-2019. Instrumen penelitian yang dianalisis dalam penelitian ini adalah annual report perusahaan untuk periode tahun 2016-2019. Teknik pengumpulan data dalam penelitian ini menggunakan dua sumber, yaitu: (1) Studi pustaka dengan yang relevan dengan obyek penelitian ini guna memperoleh bahan kepustakaan terutama teori yang mendukung topik penelitian ini, dan (2) Dokumentasi beberapa laporan perusahaan yang diperlukan untuk analisis data penelitian ini. Data diakses melalui website resmi BEI, yaitu www.idx.co.id.

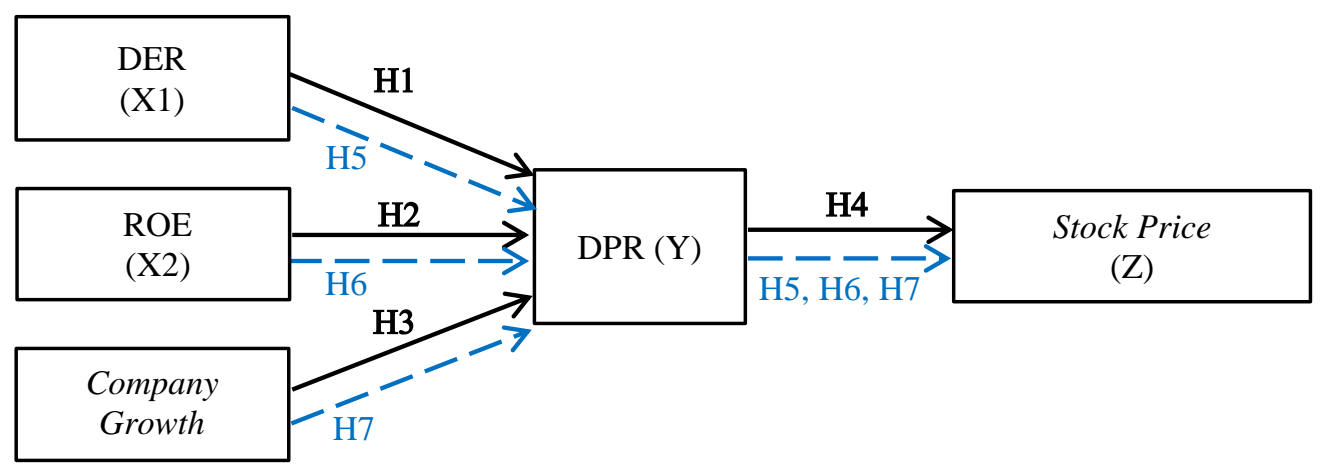

Keterangan:

$\longrightarrow \longrightarrow \begin{aligned} & =\text { pengaruh langsung } \\ & =\text { pengaruh tidak langsung (melalui variabel mediasi=Y). }\end{aligned}$

\section{Gambar 1. Model Penelitian}

Variabel dependen dalam penelitian ini adalah harga saham perusahaan sampel, sedangkan variabel independen terdiri atas DER (debt to equity ratio), ROE (return on equity), dan pertumbuhan perusahaan (company growth). Dalam penelitian ini, pertumbuh- 
an perusahaan diukur berdasarkan asset growth perusahaan. Selanjutnya, variabel mediasi atau intervening dalam penelitian ini adalah DPR (devidend payout ratio). Teknik analisis yang digunakan dalam penelitian ini meliputi: (1) Uji Asumsi Klasik yang terdiri atas uji normalitas, uji multikolonieritas, uji autokorelasi, dan uji heteroskedastisitas; (2) Analisis Regresi Linear Berganda; (3) Goodness of Fit yang dilihat dari koefisien determinasi ( $\left.\mathrm{R}^{2}\right)$, uji parsial ( $t$-test), dan analisis jalur (path analysis) dengan bantuan software SPSS versi 23. Berdasarkan kajian teoritis dan hipotesis yang diajukan dalam penelitian ini, maka model penelitian ini ditunjukkan pada Gambar 1 .

\section{HASIL DAN PEMBAHASAN}

\section{Uji Asumsi Klasik}

\section{a) Uji Normalitas}

Penelitian ini menggunakan uji normalitas berdasarkan teknik Komogorov-Smirnov dengan dua tahap berdasarkan taraf signifikansi 5\% atau 0,05. Apabila hasil uji menunjukkan taraf signifikansi lebih besar dari 0,05, maka data penelitian tersebut berdistribusi normal atau sebaliknya (Ghozali, 2018). Berdasarkan hasil olah data menggunakan SPSS versi 23, hasil uji Kolmogorov-Smirnov dalam penelitian ini yang ditunjukkan pada Tabel 1 (tahap 1) dan Tabel 2 (tahap 2) mendapatkan nilai signifikansi pada nilai Asymp. Sig. (2tailed) sebesar 0,200 atau lebih besar dari 0,05, sehingga hasil tersebut membuktikan bahwa data penelitian ini berdistribusi normal.

Tabel 1. Hasil Uji Kolmogorov-Smirnov Tahap 1

\begin{tabular}{lr}
\hline & \multicolumn{2}{c}{$\begin{array}{c}\text { Unstandardized } \\
\text { Residual }\end{array}$} \\
\hline $\mathrm{N}$ & 16 \\
\hline Test Statistic & 0,155 \\
\hline Asymp. Sig. (2-tailed) & 0,200 \\
\hline Sumber: Output SPSS versi 23 (2021). &
\end{tabular}

Tabel 2. Hasil Uji Kolmogorov-Smirnov Tahap 2

\begin{tabular}{lr}
\hline & $\begin{array}{c}\text { Unstandardized } \\
\text { Residual }\end{array}$ \\
\hline $\mathrm{N}$ & 16 \\
\hline Test Statistic & 0,170 \\
\hline Asymp. Sig. (2-tailed) & 0,200 \\
\hline
\end{tabular}

Sumber: Output SPSS versi 23 (2021).

\section{b) Uji Multikolinearitas}

Variance inflation factor (VIF) adalah faktor inflasi penyimpangan baku kuadrat. Apabila nilai tolerance lebih besar dari 0,10 dan nilai VIF kurang dari 10, maka model penelitian tidak mengandung gejala multikolinearitas (Ghozali, 2018). Menurut Ghozali (2018) pengujian multikolinearitas bertujuan untuk menguji apakah model regresi ditemukan adanya korelasi antar variabel bebas (independen). Pengujian multikolinearitas adalah pengujian yang mempunyai tujuan untuk menguji apakah dalam model regresi ditemukan adanya korelasi antara variabel independen. Berdasarkan hasil olah data menggunakan SPSS versi 23, hasil uji multikolinearitas yang ditunjukkan pada Tabel 3 (tahap 1) dan Tabel 4 (tahap 2) menghasilkan nilai toleransi semua variabel lebih besar dari 0,1 dan VIF kurang dari 10, sehingga dapat ditarik kesimpulan bahwa tidak terjadi gejala multikolinearitas dalam model penelitian ini. 
Tabel 3. Hasil Uji Multikolonieritas Tolerance dan VIF Tahap 1

\begin{tabular}{llcc}
\hline & & \multicolumn{2}{c}{ Collinearity Statistics } \\
\multicolumn{1}{c}{ Model } & Tolerance & VIF \\
\hline 1 & (Constant) & \multicolumn{2}{c}{} \\
\cline { 2 - 4 } & DER & 0,496 & 2,017 \\
\cline { 2 - 3 } & ROE & 0,450 & 2,224 \\
\cline { 2 - 3 } & GROWTH & 0,570 & 1,754 \\
\hline
\end{tabular}

Dependent variable: DPR

Sumber: Output SPSS versi 23 (2021).
Tabel 4. Hasil Uji Multikolonieritas Tolerance dan VIF Tahap 2

\begin{tabular}{llrr}
\hline \multirow{2}{*}{ Model } & \multicolumn{2}{c}{ Collinearity Statistics } \\
\cline { 2 - 3 } & Tolerance & VIF \\
\hline 1 (Constant $)$ & & \\
\cline { 2 - 3 } DER & 0,338 & 2,962 \\
\hline ROE & 0,390 & 2,563 \\
\hline GROWTH & 0,541 & 1,848 \\
\hline DPR & 0,337 & 2,972 \\
\hline
\end{tabular}

Dependent Variable: CLOSE

Sumber: Output SPSS versi 23 (2021)

\section{c) Uji Autokorelasi}

Menurut Ghozali (2018), autokorelasi muncul karena observasi yang berurutan sepanjang waktu berkaitan satu sama lainnya. Permasalahan ini muncul karena residual tidak bebas dari satu observasi ke observasi lainnya. Model regresi yang tepat adalah model regresi yang bebas dari autokolerasi. Uji autokorelasi ditunjukkan oleh hasil uji DW (Durbin-Watson). Menurut Santoso (2014), kriteria pengambilan keputusan uji autokorelasi adalah:

- Jika DW < -2 maka model penelitian mengandung autokorelasi positif.

- Jika $-2<$ DW $<2$ maka model penelitian tidak mengandung autokorelasi.

- Jika DW > 2 maka model penelitian mengandung autokorelasi negatif.

Hasil olah data menggunakan SPSS versi 23 pada Tabel 5 (tahap 1) memperoleh nilai uji Durbin-Watson (DW) sebesar 0,933, sedangkan Tabel 6 (tahap 2) menunjukkan nilai uji DW sebesar 1,963. Nilai DW pada Tabel 5 (tahap 1) dan pada Tabel 6 (tahap 2) berada pada kisaran nilai -2 dan $2(-2<\mathrm{DW}<2)$, sehingga hasil tersebut menunjukkan bahwa model penelitian ini tidak mengandung autokorelasi.

Tabel 5. Hasil Uji Autokorelasi Tahap 1

Tabel 6. Hasil Uji Autokorelasi Tahap 2

\begin{tabular}{|c|c|c|c|}
\hline Model & Durbin-Watson & Model & Durbin-Watson \\
\hline 1 & 0,933 & 1 & 1,963 \\
\hline $\begin{array}{l}\text { Predicto } \\
\text { Depende }\end{array}$ & $\begin{array}{l}\text {, GROWTH, DER, ROE. } \\
\text { OPR }\end{array}$ & $\begin{array}{l}\text { a. Predictors: } \\
\text { b. Dependent }\end{array}$ & $\begin{array}{l}\text {, GROWTH, ROE, DER. } \\
\text { Saham. }\end{array}$ \\
\hline
\end{tabular}

\section{d) Uji Heteroskedastisitas}

Menurut Ghozali (2018), uji heteroskedastisitas bertujuan untuk menguji apakah model regresi terjadi ketidaksamaan variance dari residual satu pengamatan ke pengamatan lainnya. Penelitian ini menggunakan uji scatterplot. Berdasarkan hasil olah data menggunakan SPSS versi 23 yang ditunjukkan pada Gambar 3 dan Gambar 4, maka titik scatterplot secara acak menyebar pada sumbu Y dan tidak membentuk suatu pola tertentu, sehingga hasil tersebut dapat diartikan bahwa model regresi pada penelitian ini tidak mengalami gejala heterokedastisitas. 


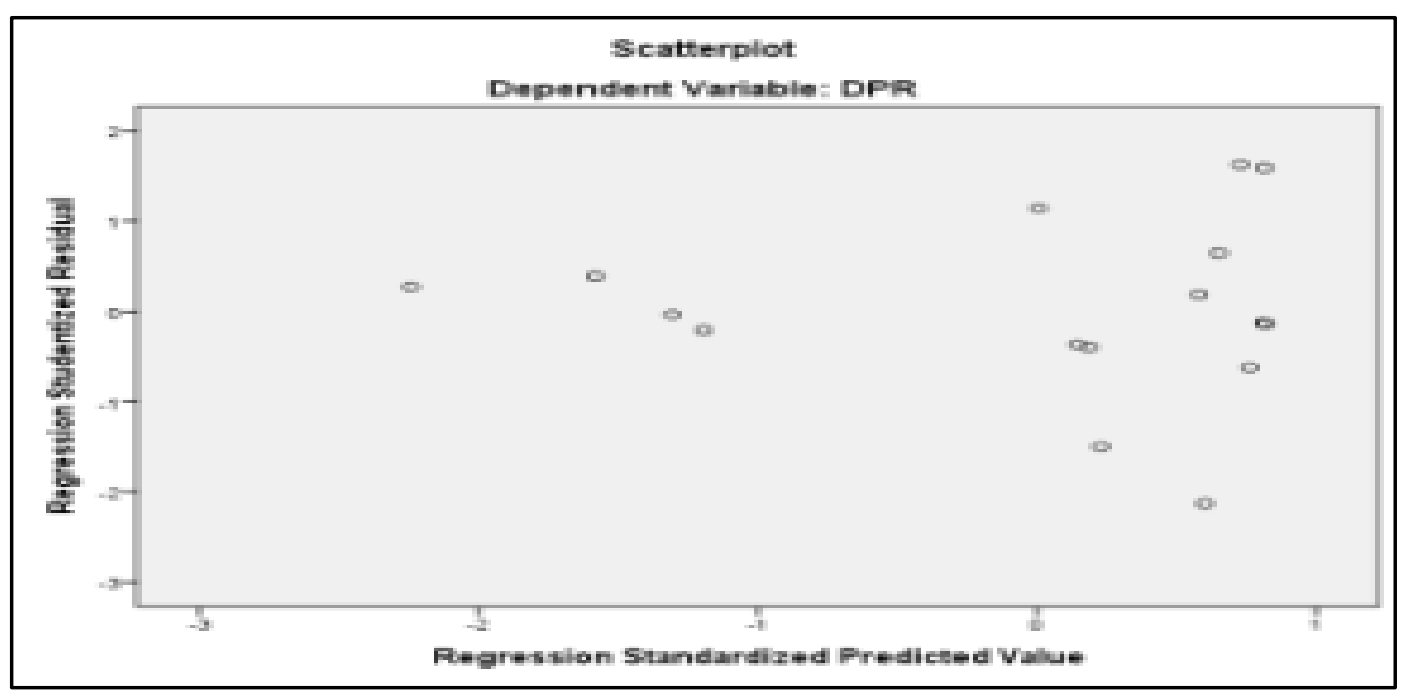

Sumber: Output SPSS versi 23 (2021).

\section{Gambar 3. Uji Heteroskedastisitas Berdasarkan Scatterplot Tahap 1}

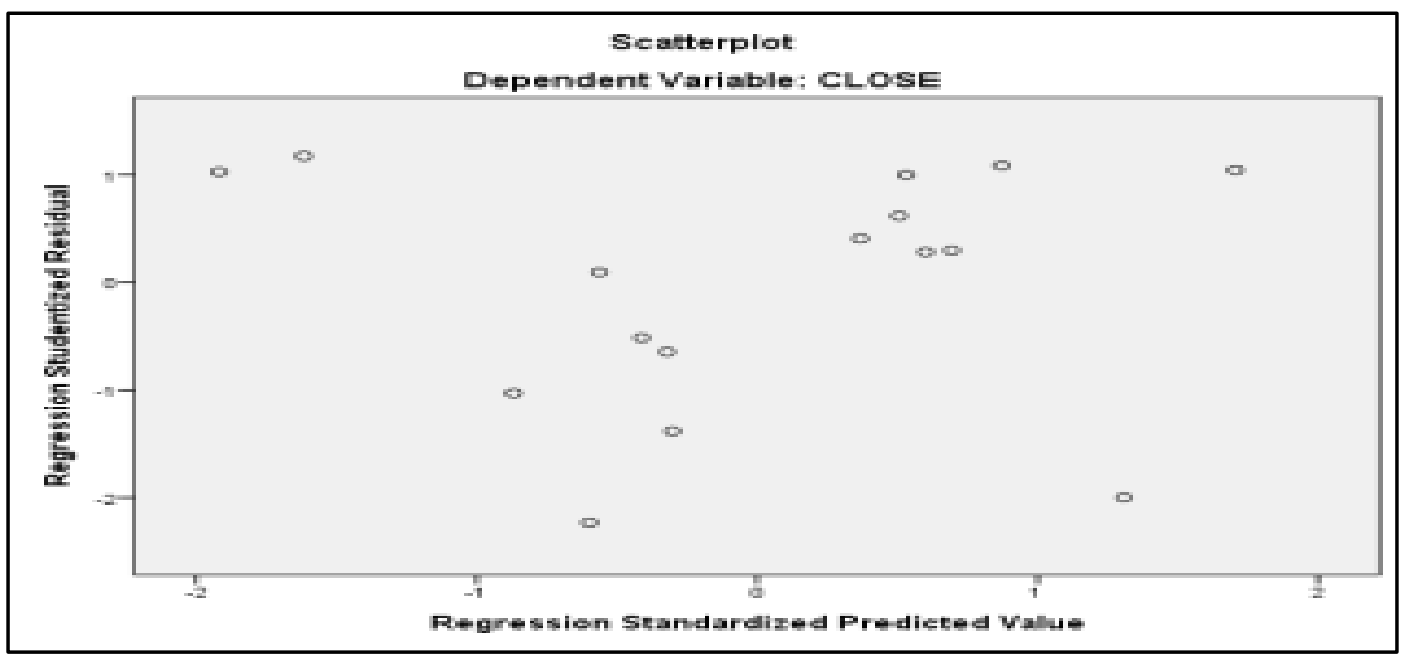

Sumber: Output SPSS versi 23 (2021).

Gambar 4. Uji Heteroskedastisitas Berdasarkan Scatterplot Tahap 2

\section{Analisis Regresi Linear Berganda}

Dari hasil olah data menggunakan SPSS versi 23 diperoleh persamaan regresi tahap 1, yaitu persamaan [5] yang didasarkan pada hasil uji regresi linear berganda tahap 1 yang ditunjukkan pada Tabel 7. 


$$
Y=50,063-3,682 X_{1}+1,273 X_{2}-0,431 X_{3}+e
$$

Keterangan:

$\mathrm{Y}=$ Dividend Payout Ratio $(\mathrm{DPR})$

$\mathrm{X} 1=$ Debt to Equity Ratio (DER)

$\mathrm{X} 2=$ Return on Equity (ROE)

$\mathrm{X} 3$ = Pertumbuhan Perusahaan (GROWTH).

Persamaan regresi linear berganda pada persamaan [5] dapat diartikan sebagai berikut:

- Nilai konstanta dalam penelitian ini adalah 50,063 yang dapat diartikan jika DER, ROE, dan pertumbuhan perusahaan diasumsikan sama dengan 0 (nol), maka DPR bernilai konstanta yaitu 50,063.

- $b 1=-3,682$ yang diartikan bahwa jika variabel lain diasumsikan konstan, maka setiap peningkatan 1\% DER akan menyebabkan DPR turun sebesar 3,682.

- $\mathrm{b} 2=1,273$ yang diartikan jika variabel lain diasumsikan konstan, maka setiap peningkatan 1\% ROE akan menyebabkan DPR naik sebesar 1,273.

- $b 3=-0,431$ yang diartian jika variabel lain diasumsikan konstan, maka setiap peningkatan $1 \%$ pertumbuhan perusahaan akan menyebabkan DPR turun sebesar 0,431.

Tabel 7. Hasil Uji Regresi Linear Berganda Tahap 1

\begin{tabular}{|c|c|c|c|c|c|c|}
\hline & \multirow{2}{*}{ Model } & \multicolumn{2}{|c|}{$\begin{array}{c}\text { Unstandardized } \\
\text { Coefficients }\end{array}$} & \multirow{2}{*}{$\begin{array}{c}\begin{array}{c}\text { Standardized } \\
\text { Coefficients }\end{array} \\
\text { Beta }\end{array}$} & \multirow[t]{2}{*}{$\mathbf{t}$} & \multirow[t]{2}{*}{ Sig. } \\
\hline & & B & Std. Error & & & \\
\hline \multirow[t]{4}{*}{1} & (Constant) & 50,063 & 17,526 & & 2,857 & 0,014 \\
\hline & DER & $-3,682$ & 1,553 & $-0,564$ & $-2,371$ & 0,035 \\
\hline & ROE & 1,273 & 0,941 & 0,338 & 1,353 & 0,201 \\
\hline & GROWTH & $-0,431$ & 0,535 & $-0,179$ & $-0,806$ & 0,436 \\
\hline
\end{tabular}

Dependent Variable: DPR

Sumber: Output SPSS versi 23 (2021).

Persamaan [6] didasarkan pada hasil uji regresi linear berganda tahap 2 yang ditunjukkan hasilnya pada Tabel 8.

$$
\mathrm{Z}=\mathbf{2 2 . 7 8 9 , 9 9 3}-1.607,892 \mathrm{X}_{1}-\mathbf{5 7 4}, 153 \mathrm{X}_{2}+180,830 \mathrm{X}_{3}-27,227 \mathrm{Y}+\mathrm{e}
$$

Keterangan:

$\mathrm{Z} \quad=$ Harga saham

$\mathrm{X} 1=$ Debt to Equity Ratio (DER)

$\mathrm{X} 2=$ Return on Equity (ROE)

$\mathrm{X} 3$ = Pertumbuhan Perusahaan (GROWTH)

$\mathrm{Y}=$ Dividend Payout Ratio (DPR).

Berdasarkan persamaan [6], hasil tersebut dapat diartikan bahwa:

- Nilai konstanta dalam penelitian ini adalah sebesar 22.789,933 artinya jika DER, ROE, pertumbuhan perusahaan, dan DPR diasumsikan sama dengan 0 (nol), maka harga saham sebesar 22.789,933.

- $\quad$ b1 $=-1.067,892$ artinya jika variabel lain diasumsikan konstan, maka setiap peningkatan 1\% DER akan menyebabkan harga saham turun sebesar 1.067,892. 
- $b 2=-574,153$ artinya jika variabel lain diasumsikan konstan, maka setiap peningkatan $1 \%$ ROE akan menyebabkan harga saham turun sebesar 574,153.

- $\quad b 3=180,830$ artinya jika variabel lain diasumsikan konstan, maka setiap peningkatan $1 \%$ pertumbuhan perusahaan akan menyebabkan harga saham naik sebesar 180,830.

- $\quad b 4=-27,227$ artinya jika variabel lain diasumsikan konstan, maka setiap peningkatan $1 \%$ DPR akan menyebabkan harga saham turun sebesar 27,227.

Tabel 8. Hasil Uji Regresi Linear Berganda Tahap 2

\begin{tabular}{|c|c|c|c|c|c|c|}
\hline & \multirow{2}{*}{ Model } & \multicolumn{2}{|c|}{ Unstandardized Coefficients } & \multirow{2}{*}{$\begin{array}{c}\begin{array}{c}\text { Standardized } \\
\text { Coefficients }\end{array} \\
\text { Beta }\end{array}$} & \multirow{2}{*}{$\mathbf{t}$} & \multirow{2}{*}{ Sig. } \\
\hline & & B & Std. Error & & & \\
\hline \multirow[t]{5}{*}{1} & (Constant) & 22789,993 & 4819,037 & & 4,729 & 0,001 \\
\hline & DER & $-1607,892$ & 399,217 & $-1,197$ & $-4,028$ & 0,002 \\
\hline & ROE & $-574,153$ & 214,350 & $-0,741$ & $-2,679$ & 0,021 \\
\hline & $G R O W T H$ & 180,830 & 116,584 & 0,364 & 1,551 & 0,149 \\
\hline & DPR & $-27,227$ & 61,241 & $-0,132$ & $-0,445$ & 0,665 \\
\hline
\end{tabular}

Dependent Variable: HARGA SAHAM

Sumber: Output SPSS versi 23 (2021).

\section{Goodness of Fit Menggunakan Koefisien Determinasi $\left(\mathbf{R}^{2}\right)$}

Berdasarkan hasil olah data SPSS versi 23 pada Tabel 9 (tahap 1) diperoleh nilai koefisien determinasi $\left(\mathrm{R}^{2}\right)$ sebesar 0,663 . Hasil tersebut dapat diartikan bahwa ketiga variabel independen yaitu DER, ROE, dan pertumbuhan perusahaan mampu menjelaskan variasi pada variabel dependen yaitu DPR sebesar 66,3\%, sedangkan sisanya sebesar 33,7\% dijelaskan oleh faktor lain yang tidak diteliti dalam model penelitian ini.

Tabel 9. Hasil Uji Koefisien Determinasi Tahap 1

\begin{tabular}{lcccc}
\hline Model & $\mathbf{R}$ & R Square & $\begin{array}{c}\text { Adjusted } R \\
\text { Square }\end{array}$ & $\begin{array}{c}\text { Std. Error of the } \\
\text { Estimate }\end{array}$ \\
\hline 1 & $0,815^{\text {a }}$ & 0,663 & 0,579 & 9,729 \\
\hline${ }^{a}$ Predictors: (Constant), GROWTH, DER, ROE. \\
Sumber: Output SPSS versi $23(2021)$.
\end{tabular}

Pada tahap 2 berdasarkan hasil olah data SPSS versi 23 yang ditunjkkan pada Tabel 10 diperoleh nilai koefisien determinasi $\left(\mathrm{R}^{2}\right)$ sebesar 0,672 . Hasil tersebut menunjukkan bahwa keempat variabel independen DER, ROE, pertumbuhan perusahaan, dan DPR mampu menjelaskan variasi pada harga saham sebesar $67,2 \%$, sedangkan sisanya sebesar $32,8 \%$ dijelaskan oleh faktor lain yang tidak diteliti dalam model penelitian ini. Dari kedua uji koefisien determinasi tersebut, model penelitian ini dapat dinyatakan cukup baik untuk menjelaskan hubungan antarvariabel yang dianalisis dalam penelitian ini. 
Tabel 10. Hasil Uji Koefisien Determinasi Tahap 2

\begin{tabular}{lcccc}
\hline Model & R & R Square & $\begin{array}{c}\text { Adjusted } R \\
\text { Square }\end{array}$ & $\begin{array}{c}\text { Std. Error of the } \\
\text { Estimate }\end{array}$ \\
\hline $\begin{array}{l}\text { S } \\
0,820^{\mathrm{a}}\end{array}$ & 0,672 & 0,553 & 2063,892 \\
${ }^{\mathrm{a}}$ Predictors: (Constant), DPR, GROWTH, ROE, DER. \\
Sumber: Output SPSS versi $23(2021)$.
\end{tabular}

\section{a) Uji Hipotesis (t-test)}

\section{Pengaruh Debt to Equity Ratio (DER) terhadap Dividend Payout Ratio (DPR)}

Hasil olah data SPSS yang ditunjukkan pada Tabel 7 diperoleh nilai signifikansi kurang dari 0,05 yaitu 0,035 dan nilai $t_{\text {hitung }} 2,371$ yang lebih besar dari $t_{\text {tabel }} 2,179$. Hasil tersebut dapat diartikan DER berpengaruh signifikan terhadap DPR atau H1 diterima. Jika Debt to Equity Ratio (DER) perusahaan mengalami kenaikan, maka dividen yang dibayarkan akan semakin besar, sehingga nilai Dividend Payout Ratio (DPR) pun akan mengalami kenaikan. Hasil penelitian ini sejalan dengan penelitian terdahulu oleh Perpatih (2016), Ulfa dan Yuniati (2016), serta Wahyuni dan Hafiz (2018) yang menyatakan bahwa DER berpengaruh signifikan terhadap DPR. Temuan ini menunjukkan bahwa DER secara langsung mempengaruhi kebijakan perusahaan membayarkan dividen. Hal ini sesuai dengan teori yang mengatakan bahwa semakin besar utang yang dimiliki perusahaan, maka kondisi itu akan berpengaruh terhadap laba perusahaan (Karjono, 2019). Dengan demikian, perusahaan cenderung lebih memilih untuk membayar utang daripada membagi dividennya.

\section{Pengaruh Return on Equity (ROE) terhadap Dividend Payout Ratio (DPR)}

Hasil olah data SPSS pada Tabel 7 diperoleh nilai signifikansi lebih besar dari 0,05 yaitu 0,201 dan nilai $t_{\text {hitung }} 1,353$ kurang dari $t_{\text {tabel }} 2,179$. Artinya, ROE tidak berpengaruh signifikan terhadap DPR atau H2 ditolak. Naik turunnya nilai DER perusahaan tidak berpengaruh terhadap jumlah dividen yang dibayarkan. Hasil penelitian ini bertolak belakang dengan penelitian terdahulu yang dilakukan oleh Nerviana (2015), Sulaeman (2018), dan Purba et al. (2019) yang menyatakan bahwa ROE berpengaruh signifikan terhadap DPR. Profitabilitas merupakan salah satu faktor yang mempengaruhi kebijakan dividen. ROE difungsikan sebagai salah satu tolok ukur kinerja keuangan perusahaan yang dapat digunakan para investor untuk melihat tingkat keberhasilan perusahaan. Jika hasil ROE tidak berpengaruh terhadap DPR, maka kinerja perusahaan dalam pembagian dividen diindikasikan kurang baik.

\section{Pengaruh Pertumbuhan Perusahaan terhadap Dividend Payout Ratio (DPR)}

Berdasarkan hasil olah data SPSS pada Tabel 7, nilai signifikansi variabel pertumbuhan perusahaan lebih besar dari 0,05 yaitu 0,436 dan nilai thitung 0,806 kurang dari $t_{\text {tabel }}$ 2,179 . Hasil tersebut mengindikasikan bahwa pertumbuhan perusahaan tidak berpengaruh signifikan terhadap DPR atau H3 ditolak. Naik turunnya pertumbuhan perusahaan tidak berpengaruh terhadap jumlah dividen yang dibayarkan perusahaan. Hasil penelitian ini bertolak belakang dengan penelitian terdahulu yang dilakukan oleh Sari dan Sudjarni (2015), Silaban dan Purnawati (2016), serta Pambayun dan Sulasmiyati, (2017) yang menyatakan 
bahwa pertunbuhan perusahaan berpengaruh signifikan terhadap DPR. Pertumbuhan perusahaan dapat difungsikan sebagai indikator untuk menilai kebijakan dividen perusahaan. Semakin tinggi pertumbuhan perusahaan, maka semakin besar dana yang dibutuhkan perusahaan. Jika dana yang dibutuhkan semakin besar, maka perusahaan lebih memilih untuk menahan laba perusahaan daripada membagi dividen kepada para pemegang saham.

\section{Pengaruh Dividend Payout Ratio (DPR) terhadap Harga Saham}

Berdasarkan hasil olah data pada Tabel 8, nilai signifikansi variabel DPR lebih besar dari 0,05 yaitu 0,665 dan nilai $t_{\text {hitung }} 0,445$ lebih besar dari $t_{\text {tabel }} 2,201$. Hasil tersebut menunjukkan bahwa DPR tidak berpengaruh signifikan terhadap harga saham atau H4 ditolak. Besar kecilnya jumlah dividen yang dibayarkan perusahaan tidak berpengaruh terhadap perubahan harga saham perusahaan tersebut. Hasil penelitian ini bertolak belakang dengan penelitian terdahulu oleh Clarensia et al. (2012), Oktaviani dan Agustin (2017), serta Estiasih et al. (2020) yang menyatakan bahwa DPR berpengaruh signifikan terhadap harga saham. Tingginya nilai DPR menunjukkan bahwa keuntungan perusahaan juga semakin tinggi. Kondisi tersebut menunjukkan bahwa pembagian laba terhadap investor juga semakin meningkat. Namun, hasil yang diperoleh adalah sebaliknya, yaitu nilai DPR perusahaan belum mampu memberikan keuntungan lebih bagi perusahaan terkait dengan harga sahamnya.

\section{b) Analisis Jalur}

Analisis jalur (Path Analysis) digunakan untuk mengetahui adanya pengaruh langsung dan pengaruh tidak langsung antara variabel DER, ROE, Pertumbuhan Perusahaan, DPR dan Harga Saham. Hasil koefisien analisis jalur di tampilkan pada Gambar 2, sedangkan rangkuman hasil analisis jalur pada penelitian ini ditunjukkan pada Tabel 12.

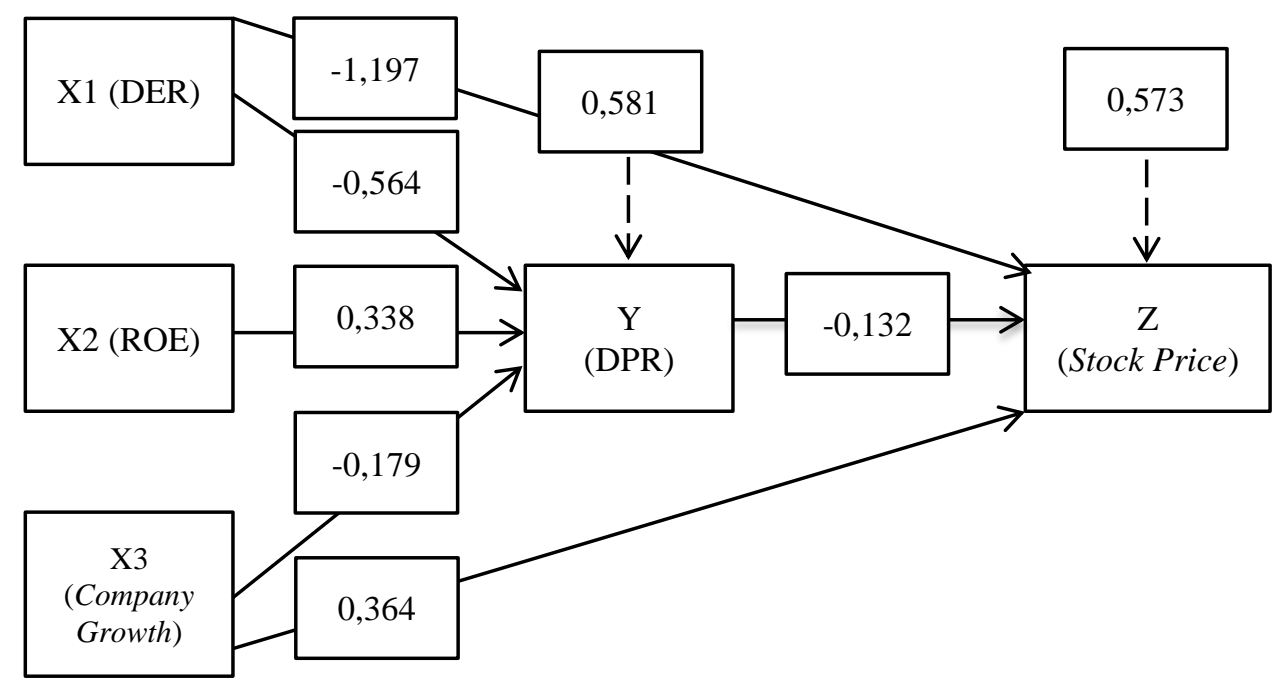

Gambar 2. Path Analysis 
Tabel 12. Analisis Jalur

\begin{tabular}{|c|c|c|c|c|c|c|c|c|c|c|c|}
\hline \multicolumn{4}{|c|}{ Pengaruh $X_{1}$ ke $Z$ melalui $Y$} & \multicolumn{4}{|c|}{ Pengaruh $\mathrm{X}_{2}$ ke $\mathrm{Z}$ melalui $\mathrm{Y}$} & \multicolumn{4}{|c|}{ Pengaruh $\mathrm{X}_{2}$ ke $\mathrm{Z}$ melalui $\mathrm{Y}$} \\
\hline $\mathrm{X}_{1} \rightarrow \mathrm{Y}$ & $\underset{\mathrm{Y}}{\mathrm{X}_{1} \rightarrow}$ & $\begin{array}{l}\mathrm{X}_{1} \rightarrow \\
\mathrm{Y} \rightarrow \mathrm{Z}\end{array}$ & $\begin{array}{c}\Sigma X_{1} \\
\rightarrow Z\end{array}$ & $\mathrm{X}_{2} \rightarrow \mathrm{Z}$ & $\underset{\mathrm{Y}}{\mathrm{X}_{2} \rightarrow}$ & $\begin{array}{c}\mathrm{X}_{2} \rightarrow \\
\mathrm{Y} \rightarrow \mathrm{Z}\end{array}$ & $\begin{array}{c}\Sigma X_{2} \\
\rightarrow Z\end{array}$ & $\mathrm{X}_{2} \rightarrow \mathrm{Z}$ & $\begin{array}{c}\mathrm{X}_{1} \rightarrow \\
\mathrm{Y}\end{array}$ & $\begin{array}{c}\mathrm{X}_{1} \rightarrow \\
\mathrm{Y} \rightarrow \mathrm{Z}\end{array}$ & $\begin{array}{l}\Sigma X_{1} \\
\rightarrow Z\end{array}$ \\
\hline$-1,197$ & $-0,564$ & 0,075 & $-1,122$ & $-0,741$ & 0,338 & $-0,045$ & $-0,786$ & 0,364 & $-0,179$ & 0,024 & 0,388 \\
\hline
\end{tabular}

Keterangan:

$\mathrm{X}_{1}=\mathrm{DER} ; \mathrm{X}_{2}=\mathrm{ROE} ; \mathrm{X}_{3}=$ Company Growth $\mathrm{Y}=\mathrm{DPR} ; \mathrm{Z}=$ Stock Price.

Sumber: Output SPSS versi 23 (2021).

\section{Pengaruh Debt to Equity Ratio (DER) terhadap Harga Saham melalui Dividend Payout Ratio (DPR)}

Berdasarkan hasil analisis jalur yang ditunjukkan pada Gambar 2 dan Tabel 12, nilai pengaruh tidak langsung DER terhadap harga saham melalui DPR lebih besar pengaruh langsung DER terhadap harga saham, yaitu 0,075>-1,197. Temuan tersebut menunjukkan bahwa DER berpengaruh signifikan terhadap harga saham melalui DPR atau H5 diterima. Jika nilai DER perusahaan meningkat, maka dividen yang dibayarkan perusahaan pun akan mengalami peningkatan, sehingga hal itu secara tidak langsung dapat berpengaruh terhadap perubahan harga saham. Hasil penelitian ini sejalan dengan penelitian terdahulu oleh Devi dan Sutrisno T. (2015), Ariyani et al. (2018), serta Lestari dan Susetyo (2020) yang menyatakan bahwa DER berpengaruh tidak langsung terhadap harga saham melalui DPR. Hal ini mengindikasikan bahwa utang yang dimiliki perusahaan belum mampu mempengaruhi harga saham perusahaan, meskipun nilai dividen yang diterima para pemilik saham meningkat.

\section{Pengaruh Return on Equity (ROE) terhadap Harga Saham melalui Dividend Payout Ratio (DPR)}

Berdasarkan hasil olah data yang ditunjukkan pada Gambar 2 dan Tabel 12. pengaruh tidak langsung ROE terhadap harga saham melalui DPR lebih besar dari pengaruh langsung ROE terhadap harga saham secara langsung, yaitu $-0,045>-0,741$. Hasil tersebut menunjukkan bahwa ROE berpengaruh signifikan terhadap harga saham melalui DPR atau H6 diterima. Jika nilai ROE perusahaan meningkat, maka dividen yang dibayarkan perusahaan pun juga akan mengalami peningkatan, sehingga ROE secara tidak langsung berpengaruh terhadap perubahan harga saham perusahaan. Temuan ini didukung oleh penelitian terdahulu oleh Pramana dan Pangestuti (2016) serta Satar dan Jayanti (2020) yang menyatakan bahwa kebijakan dividen dapat memediasi pengaruh ROE terhadap harga saham. Berdasarkan temuan yang diperoleh dari pengujian ini menunjukkan bahwa nilai profitabilitas atau ROE perusahaan mampu meningkatkan nilai harga saham perusahaan. Kondisi tersebut juga mempengaruhi nilai dividen yang secara tidak langsung akan meningkat seiring dengan meningkatnya nilai laba.

\section{Pengaruh Pertumbuhan Perusahaan terhadap Harga Saham melalui Dividend Payout Ratio (DPR)}

Berdasarkan hasil olah data yang ditampilkan pada Gambar 2 dan Tabel 12, nilai pengaruh tidak langsung company growth terhadap harga saham melalui DPR lebih besar dari pengaruh langsung company growth terhadap harga saham, yaitu $0,024<0,364$. Temuan ini menunjukkan bahwa company growth tidak berpengaruh signifikan terhadap harga 
saham melalui DPR atau H7 ditolak. Hasil ini selaras dengan penelitian terdahulu oleh Deitiana (2012) yang menyatakan bahwa pertumbuhan perusahaan tidak berpengaruh signifikan terhadap harga saham melalui DPR. Pertumbuhan perusahaan yang baik akan mempengaruhi harga saham perusahaan. Jika pertumbuhan perusahaan meningkat, maka laba yang diperoleh perusahaan juga akan meningkat. Kondisi tersebut secara langsung berkaitan dengan peningkatan nilai dividen yang dibagikan perusahaan.

\section{KESIMPULAN DAN SARAN}

\section{Kesimpulan}

Berdasarkan hasil penelitian dan pembahasan dalam penelitian ini, maka temuan penting penelitian ini adalah Debt to Equity Ratio (DER) berpengaruh signifikan terhadap Dividend Payout Ratio (DPR) pada perusahaan perbankan BUMN periode tahun 20162019, sedangkan Return on Equity (ROE) dan pertumbuhan perusahaan (company growth) tidak berpengaruh signifikan terhadap Dividend Payout Ratio (DPR) pada perusahaan perbankan BUMN untuk periode yang sama. Selanjutnya, Dividend Payout Ratio (DPR) tidak berpengaruh signifikan terhadap harga saham perusahaan perbankan BUMN tahun 2016-2019. Namun, Debt to Equity Ratio (DER) dan Return on Equity (ROE) berpengaruh signifikan terhadap harga saham melalui Dividend Payout Ratio (DPR) pada perusahaan perbankan BUMN periode tahun 2016-2019. Di sisi lain, pertumbuhan perusahaan tidak berpengaruh signifikan terhadap harga saham melalui Dividend Payout Ratio (DPR) pada perusahaan perbankan BUMN tahun 2016-2019.

\section{Saran}

Perusahaan yang mampu bersaing dan memperoleh kepercayaan investor merupakan perusahaan yang mampu meningkatkan kinerja perusahaannya, sehingga perusahaan tersebut lebih mudah mendapatkan modal dari luar perusahaan. Untuk penelitian mendatang, para peneliti yang ingin mengembangkan temuan penelitian ini dapat menggunakan ruang lingkup yang lebih luas. Cakupan penelitian mendatang tidak hanya terbatas pada perusahaan perbankan BUMN, tetapi cakupan dapat meluas ke seluruh perusahaan perbankan yang listing di BEI, atau perbankan terbesar se-ASEAN, atau se-Asia, atau perbankan terbesar di dunia. Selain itu, variabel yang digunakan dalam penelitian dapat lebih ditambah variasinya melalui penambahan variabel dependen, independen, atau juga keduanya, misalnya Working Capital Turn Over, Capital Adequacy Ratio (CAR), Price Book Value (PBV), atau variabel lain yang tidak diteliti dalam penelitian ini.

\section{DAFTAR REFERENSI}

Anjasari, D. R., Florencia, M., \& Hidayat N., R. (2020). Pengaruh Return on Asset, Return on Equity, Earning Per Share terhadap Harga Saham. Jurnal Ilmiah Manajemen Ubhara, 2(2), 123-130. https://doi.org/10.31599/jmu.v2i2.774.

Ariyani, L., Andini, R., \& Santoso, E. B. (2018). Pengaruh EPS, CR, DER, dan PBV terhadap Harga Saham dengan Kebijakan Dividen sebagai Variabel Intervening (Studi pada Perusahaan Manufaktur yang Terdaftar di BEI Tahun 2011-2015). 
Journal of Accounting: Jurnal Ilmiah Mahasiswa S1 Akuntansi Universitas Pandanaran, 4(4), 1-20.

Astiti, N. K. A., Yuniarta, G. A., Sujana, E. (2017). Pengaruh Debt To Equity Ratio (DER), Current Ratio (CR), Net Present Margin (NPM), Return on Asset (ROA) terhadap Dividend Payout Ratio (DPR) Studi pada Perusahaan Basic Industry dan Properti, Real Estate \& Building Contruction yang Terdaftar di Bursa Efek Indonesia Periode 2011-2015. JIMAT (Jurnal Ilmiah Mahasiswa Akuntansi S1) Undiksha, 7(1), 1-12.

BPS (2020). Ekonomi Indonesia 2020 Turun sebesar 2,07 persen (c-to-c). Jakarta: Badan Pusat Statistik. Diakses pada tanggal 14 Januari 2021 di https://www.bps.go.id/pressrelease/2021/02/05/1811/ekonomi-indonesia-2020-turunsebesar-2-07-persen--c-to-c-.html.

Clarensia, J., Rahayu, S., \& Azizah, N. (2012). Pengaruh likuiditas, Profitabilitas, Pertumbuhan Penjualan dan Kebijakan Dividen terhadap Harga Saham (Studi Empirik pada Perusahaan Manufaktur yang Terdaftar di Bursa Efek Indonesia Tahun 2007-2010). Jurnal Akuntansi dan Keuangan, 1(1), 72-88.

Darmadji, T., \& Fakhruddin, H. M. (2012). Pasar Modal Indonesia. Jakarta: Salemba Empat.

Deitiana, T. (2012). Pengaruh Rasio Keuangan dan Pertumbuhan Penjualan terhadap Dividen dan Implikasinya pada Harga Saham. Jurnal Akuntansi, XVI(02), 191-208.

Devi, I. N., \& Sutrisno, T. (2015). Pengaruh PBV, EPS, dan DER Terhadap Harga Saham dengan Kebijakan Deviden sebagai Variabel Intervening : Studi pada Perusahaan Manufaktur yang Terdaftar di BEI Tahun 2009-2013. Jurnal Ilmiah Mahasiswa FEB Universitas Brawijaya, 4(1), 1-21.

Diantini, O., \& Badjra, I. B. (2016). Pengaruh Earing per Share, Tingkat Pertumbuhan Perusahaan dan Current Ratio terhadap Kebijakan Dividen. E-Jurnal Manajemen. 5(11), 6795-6824.

Estiasih, S. P., Prihatiningsih, E., \& Fatmawati, Y. (2020). Dividend Payout Ratio, Earning Per Share, Debt To Equity Ratio Terhadap Harga Saham Pada Perusahaan LQ45. Jurnal Akuntansi dan Pajak, 21(01), 205-212. https://doi.org/10.29040/jap.v21i1.1156.

Febriyani, R. M. (2017). Pengaruh Return on Assets, Debt to Equity Ratio dan Deviden Payout Ratio terhadap Harga Saham. Jurnal Universitas PGRI Yogyakarta, 1(1), 111.

Ghozali, I. (2018). Aplikasi Analisis Multivariate dengan Program IBM SPSS 25. Edisi Kesembilan. Semarang: Badan Penerbit Universitas Diponegoro.

Girsang, A. N., Tambun, H. D., Putri, A., Rarasati, D., Nainggolan, D. S. S., \& Desi, P. (2019). Analisis Pengaruh EPS, DPR, dan DER terhadap Harga Saham Sektor Trade, Services, \& Investment di BEI. Jesya (Jurnal Ekonomi \& Ekonomi Syariah), 2(2), 351-362. https://doi.org/10.36778/jesya.v2i2.97.

Gitosudarmo, I., \& Basri, B. (2019). Manajemen Keuangan. Edisi 4. Yogyakarta: BPFE. Hanif, M. \& Bustamam, B. (2017). Pengaruh Debt to Equity Ratio, Return on Aset, Firm Size, dan Earning per Share terhadap Dividend Payout Ratio (Studi pada Perusahaan 
Manufaktur yang Terdaftar di Bursa Efek Indonesia Tahun 2011-2015). Jurnal Ilmiah Mahasiswa Ekonomi Akuntansi (JIMEKA), 2(1), 73-81.

Hartono, J. (2017). Teori Portofolio dan Analisis Investasi. Edisi 11. Yogyakarta: BPFE.

IDX (2021). Laporan Keuangan dan Tahunan. Perusahaan Tercatat. Jakarta, Indonesia Stock Exchange. Diakses tanggal 14 Januari 2021 di https://idx.co.id/perusahaantercatat/laporan-keuangan-dan-tahunan/.

Kumaidi, R. K., \& Asandimitra, N. (2017). Pengaruh ROA, ROE, DER, DPR, dan LDR terhadap Harga Saham Sektor Perbankan BEI Periode 2011-2016 (Dengan Penggolongan Kapitalisasi Kecil dan Kapitalisasi Besar). Jurnal Ilmu Manajemen (JIM), 5(3), 1-13.

Lestari, A. P., \& Susetyo, A. (2020). Pengaruh NPM, EPS, DER dan PBV Terhadap Harga Saham pada Perusahaan Terdaftar IDX HIDIV20 dengan DPR sebagai Variabel Intervening. Jurnal Ilmiah Mahasiswa Manajemen, Bisnis \& Akuntansi (JIMMBA), 2(2), 184-196. https://doi.org/10.32639/jimmba.v2i2.461.

Maria, R. (2019). Pengaruh Rasio Hutang dengan Total Aset, Ukuran Perusahaan, dan Pertumbuhan Aset terhadap Kebijakan Dividen Tunai pada Perusahaan Manufaktur Sub Sektor Otomotif yang Terdaftar di BEI Periode 2014-2018. Thesis, Universitas Komputer Indonesia, Bandung. http://elibrary.unikom.ac.id/id/eprint/2087.

Nerviana, R. (2015). The Effect of Financial Ratios and Company Size on Dividend Policy. The Indonesian Accounting Review, 5(1), 23-32. https://doi.org/10.14414/tiar.v5i1.486.

Nugraha, R. D., \& Sudaryanto, B. (2016). ( Studi Kasus pada Perusahaan Industri Dasar dan Kimia yang Terdaftar di BEI Periode 2010-2014 ). Diponegoro Journal of Management, 5(2006), 1-12. http://ejournal-s1.undip.ac.id/index.php/management.

Nurcahayani, R. \& Daljono, D. (2014). Analisis Pengaruh Struktur Modal terhadap Profitabilitas (Studi pada Perusahaan Manufaktur yang Terdaftar di Bursa Efek Indonesia pada Tahun 2010-2012). Diponegoro Journal of Accounting, 3(4), 123132.

Oktaviani, P. R., \& Agustin, S. (2017). Pengaruh PER, EPS , DPS , DPR terhadap Harga Saham pada Perusahaan Pertambangan. Jurnal IImu dan Riset Manajemen, 6(2), 117.

Pambayun, G. A., \& Sulasmiyati, S. (2017). Pengaruh Kepemilikan Manajerial, Debt to Equity Ratio dan Assets Growth terhadap Dividen Payout Ratio (Studi pada Perusahaan LQ-45 yang Terdaftar di Bursa Efek Indonesia Periode 2012-2015). Jurnal Administrasi Bisnis, 51(2), 118-125.

Pamungkas, N., Rusherlistyani, R., \& Janah, I. (2017). Pengaruh Return on Equity, Debt to Equity Ratio, Current Ratio, Earning per Share dan Investment Opportunity Set terhadap Kebijakkan Dividen. Jurnal Analisa Akuntansi dan Perpajakan, 1(1), 34-41.

Paramitasari, R. (2014). Analisis Faktor-Faktor yang Mempengaruhi Audit Delay pada Perusahaan LQ45 yang Terdaftar di Bursa Efek Indonesia. Jurnal Akuntansi dan Bisnis, 14(1), 129-140. https://doi.org/10.20961/jab.v14i1.149. 
Perpatih, Z. S. T. (2016). Pengaruh "ROA" dan "DER" terhadap Dividend Payout Ratio (DPR) pada Perusahaan Manufaktur Sektor Industri Dasar dan Kimia yang Terdaftar di Bursa Efek Indonesia. e-Jurnal Apresiasi Ekonomi, 4(3), 205-211.

Pramana, M. S., \& Pangestuti, I. R. D. (2016). Pengaruh Rasio Profitabilitas, Leverage, Size, dan Sales Growth terhadap Return Saham yang Dimediasi oleh Dividen (Studi pada Perusahaan Manufaktur yang Terdaftar di BEI Periode Tahun 2012-2014). Diponegoro Journal of Management, 5(3), 475-489.

Pratama, G. N., Sujana, E., \& Werastuti, D. N. (2015). Analisis Pengaruh Asset Growth, Debt to Equity Ratio (DER), Earning per Share (EPS) dan Reputasi Auditor Terhadap Dividend Payout Ratio (DPR) pada Perusahaan yang Tercantum dalam Indeks LQ45 Periode 2009-2013. E-journal S1 Ak Universitas Pendidikan Ganesha, 3(1), 1-12.

Purba, D. P., Sheren, S., Valent, V., \& Angeline, A. (2019). Pengaruh Current Ratio (Cr), Debt to Equity Ratio (DER) dan Return on Equity (ROE) terhadap Dividend Payout Ratio (DPR) pada Perusahaan Sektor Industri Barang Konsumsi di Bursa Efek Indonesia (BEI) Tahun 2013-2017. Going Concern: Jurnal Riset Akuntansi, 14(1), 214-224. https://doi.org/10.32400/gc.14.1.22647.2019.

Rohmawati, E., \& Herawati, J. (2013). Analisis Pengaruh Earning per Share, Return on Equity dan Debt to Total Asset terhadap Harga Saham pada Industri Kertas yang Tercatat di Bursa Efek Indonesia. Jurnal Ilmiah Mahasiswa FEB Universitas Brawijaya, 1(2), 1-13.

Safrida, E. (2014). Profitabilitas dan Pertumbuhan Perusahaan terhadap Kebijakan Deviden pada Perusahaan Manufaktur di Indonesia. Jurnal Riset Akuntansi dan Keuangan, 2(1), 289-299. https://doi.org/10.17509/jrak.v2i1.6582.

Samrotun, Y. C. (2015). Kebijakan Dividen dan Faktor-faktor yang Mempengaruhinya. Jurnal Paradigma, 13(01), 92-103.

Santoso, S. (2014). Panduan Lengkap SPSS Versi 20. Jakarta: PT Elex Media Komputindo.

Sari, K. A. N., \& Sudjarni, L. K. (2015). Pengaruh Likuiditas, Leverage, Pertumbuhan Perusahaan, dan Profitabilitas terhadap Kebijakan Dividen pada Perusahaan Manufaktur di BEI. E-Jurnal Manajemen Unud, 4(10), 3346-3374.

Satar, A., \& Jayanti, S. D. (2020). Pengaruh Profitabilitas dan Leverage Deviden sebagai Variabel Moderating pada Perusahaan Manufaktur yang Terdaftar di Indeks Saham Syariah Indonesia (ISSI) Tahun 2014-2018. I-Finance: A Research Journal on Islamic Finance, 06(02), 148-167. https://doi.org/10.19109///ifinace.v6i2.6679.

Silaban, D. P., \& Purnawati, N. K. (2016). Pengaruh Profitabilitas, Struktur Kepemilikan, Pertumbuhan Perusahaan dan Efektivitas Usaha terhadap Kebijakan Dividen pada Perusahaan Manufaktur. E-Jurnal Manajemen Unud, 5(2), 1251-1281.

Sugiyono, S. (2019). Metode Penelitian Kuantitatif Kualitatif dan R\&D. Bandung: CV Alfabeta.

Sulaeman, M. (2018). Pengaruh Return on Equity (ROE) terhadap Dividend Payout Ratio (DPR) (Studi pada Perusahaan Sektor Makanan dan Minuman yang Terdaftar di BEI). Prive: Jurnal Riset Akuntansi dan Keuangan, 1(1), 73-88. 
Tim Edusaham (2020). Data Kapitalisasi Pasar 2019 (Semua Emiten di Bursa Efek Indonesia). Edusaham.com, 21 Desember 2020. Diakses tanggal 14 Januari 2021 di https://www.edusaham.com/2020/01/data-kapitalisasi-pasar-perusahaan-di-bei.html.

Ulfa, L. M., \& Yuniati, T. (2016). Pengaruh Kinerja Keuangan, Asset Growth dan Firm Size terhadap Dividend Payout Ratio. Jurnal Ilmu dan Riset Manajemen, 5(5), 1-16.

Utari, D., Purwanti, A., \& Prawironegoro, D. (2014). Manajemen Keuangan: Kajian Praktek dan Teori dalam Mengelola Keuangan Organisasi Perusahaan. Edisi Revisi. Bogor: Mitra Wacana Media.

Wahyuni, S. F., \& Hafiz, M. S. (2018). Pengaruh CR, DER dan ROA terhadap DPR pada Perusahaan Manufaktur di BEI. Jesya (Jurnal Ekonomi \& Ekonomi Syariah), 1(2), 25-42. https://doi.org/10.36778/jesya.v1i2.18. 